\title{
Abscesses: an open and shut case!
}

\author{
S. M. BARNES \& P. L. MILSOM
}

Accident and Emergency Departments, Leeds General Infirmary, Leeds, and York District Hospital, York, England

\section{SUMMARY}

Thirty-seven years ago, it was suggested that abscesses could be treated with primary closure rather than by conventional incision and drainage, and that subsequent healing $\vec{S}$ was superior. The result of a survey into the practice and teaching of abscesso management in accident and emergency departments shows that, despite apparent satisfaction with the technique, it has not gained widespread acceptance. The literature $\frac{3}{\square}$ on the subject is reviewed, and from this review it would appear that there cannot be any $\mathbb{\Phi}$ justification for the traditional method of packing abscess cavities. Areas for furthgr $\overrightarrow{0}$ research are identified.

\section{INTRODUCTION}

The conventional treatment of abscesses is incision, curettage, drainage and, in some cases, deroofing prior to allowing open drainage, with or without packing. This allows healing of the cavity from the base by secondary intention. In 1951, it was suggested. that abscesses could be closed at the time of incision and drainage by primary suture (Ellis, 1951). This method however is not mentioned or is dismissed in current standard surgical textbooks (Ellis \& Calne, 1987; Cuschieri et al., 1988; Dudley, 1986).

Both the authors of this article were trained in accident and emergency (A\&E) medicine in the Yorkshire region of England where two out of four training depart- $₹$ ments use primary closure of abscesses. To those taught to treat abscesses conven- $\bigcirc$ tionally, the technique of primary closure causes concern. A review of the literature is $\frac{D}{0}$ informative.

Ellis's original paper (Ellis, 1951) described his observations on the use of antibiotics $N$ and how this led him to treat abscesses with incision, drainage and primary suture after $\widetilde{O}$ administering an antibiotic pre-operatively. All the patients were treated as outpatients. Ellis followed this original work with three further papers (Ellis, 1953, 1960, 1962).

Correspondence: S. M. Barnes, Accident and Emergency Department, Leeds General Infirmary, Great George $\stackrel{\oplus}{+}$ Street, Leeds LS1 3EX, England. 
These describe his method of treating anorectal and pilonidal abscesses and the results of two series of patients totalling 346 patients in all (Table 1). Patients were given an antibiotic pre-operatively. At operation, the abscess was incized, the granulation tissue surrounding the abscess broken down, and the abscess cavity obliterated by sutures as any remaining dead space might lead to recurrence. Dressings were changed on day 2 and sutures removed on day 4 . Reasons for delay in healing were discussed; these were skin necrosis due to prolonged conservative management prior to incision, inadequate evacuation, abscesses that were too large for the cavity to be obliterated and inadequate suturing. It is a high recurrence rate that is often cited as the reason for not using primary closure. However, a recurrence rate of $25 \%$ has been reported in anorectal abscesses treated in the conventional manner (Buchan \& Grace, 1973) and rates of $9.5 \%$, and $22 \%$ have been reported for anorectal abscesses treated by primary closure (Ellis, 1962; Wilson, 1964). It was not until 1976 that a thorough controlled study was published (Leaper et al., 1976) (Tables $1 \& 2$ ). They concluded that incision, curettage and primary closure was the superior technique as the mean healing time and time off work was significantly less. Leaper also noted that there was no increase in recurrence rate-in fact there were fewer recurrences in the outpatient group although the difference was not significant.

Anorectal abscesses are by no means the only abscesses for which primary closure has

Table 1 Summary of literature review: healing times

\begin{tabular}{|c|c|c|c|c|c|}
\hline Author & Year & $\begin{array}{l}\text { Method of } \\
\text { treatment }\end{array}$ & $\begin{array}{l}\text { Type of } \\
\text { abscesses }\end{array}$ & Numbers & $\begin{array}{l}\text { Healing } \\
\text { time } \\
\text { (days) }\end{array}$ \\
\hline Ellis & 1951 & P. Closure & Anorectal & 30 & $6 \cdot 5$ \\
\hline Ellis & 1960 & P. Closure & Anorectal & $\begin{array}{r}151 \\
22 \\
26\end{array}$ & $\begin{array}{l}7 \\
8-12 \\
>12\end{array}$ \\
\hline $\begin{array}{l}\text { Benson \& } \\
\text { Goodman }\end{array}$ & 1970 & $\begin{array}{l}\text { Conventional } \\
\text { P. Closure }\end{array}$ & $\begin{array}{l}\text { Breast } \\
\text { Breast }\end{array}$ & $\begin{array}{r}30 \\
145\end{array}$ & $\begin{array}{l}28 \\
21\end{array}$ \\
\hline Page & 1974 & P. Closure & Axillary & 111 & $6 \cdot 6$ \\
\hline Leaper et al. & 1976 & $\begin{array}{l}\text { Conventional } \\
\text { P. Closure }\end{array}$ & $\begin{array}{l}\text { Anorectal } \\
\text { Anorectal }\end{array}$ & $\begin{array}{l}109 \\
110\end{array}$ & $\begin{array}{l}35 \\
10\end{array}$ \\
\hline $\begin{array}{l}\text { Jones \& } \\
\text { Wilson }\end{array}$ & 1976 & P. Closure & Mixed & 150 & $6 \cdot 6$ \\
\hline $\begin{array}{r}\text { Macfie \& } \\
\text { Harvey }\end{array}$ & 1977 & $\begin{array}{l}\text { P. Closure V } \\
\text { Conventional }\end{array}$ & Mixed & 219 & No diff. \\
\hline Murie & 1981 & $\begin{array}{l}\text { Conventional } \\
\text { P. Closure }\end{array}$ & $\begin{array}{l}\text { Mixed } \\
\text { Mixed }\end{array}$ & $\begin{array}{l}29 \\
28\end{array}$ & $\begin{array}{c}10 \cdot 9 \\
7\end{array}$ \\
\hline Simms et al. & 1982 & $\begin{array}{l}\text { Conventional } \\
\text { P. Closure }\end{array}$ & $\begin{array}{l}\text { Mixed } \\
\text { Mixed }\end{array}$ & $\begin{array}{l}60 \\
54\end{array}$ & $\begin{array}{l}7 \cdot 8 \\
8 \cdot 9\end{array}$ \\
\hline $\begin{array}{l}\text { Stewart } \\
\text { et al. }\end{array}$ & 1985 & $\begin{array}{l}\text { Conventional } \\
\text { P. Closure }\end{array}$ & $\begin{array}{l}\text { Mixed } \\
\text { Mixed }\end{array}$ & $\begin{array}{l}73 \\
64\end{array}$ & $\begin{array}{r}21 \\
7\end{array}$ \\
\hline
\end{tabular}


Table 2 Summary of literature review: recurrence rates

\begin{tabular}{|c|c|c|c|c|c|}
\hline Author & Year & $\begin{array}{l}\text { Method of } \\
\text { treatment }\end{array}$ & $\begin{array}{l}\text { Type of } \\
\text { abscesses }\end{array}$ & Numbers & $\begin{array}{l}\text { Recurrence } \\
\text { rate }(\%)\end{array}$ \\
\hline Ellis & 1962 & P. Closure & Anorectal & 146 & $9 \cdot 5$ \\
\hline Wilson & 1964 & P. Closure & Anorectal & 100 & 22 \\
\hline $\begin{array}{c}\text { Buchan \& } \\
\text { Grace }\end{array}$ & 1973 & Conventional & Anorectal & & 25 \\
\hline Benson \& & 1970 & Conventional & Breast & 30 & $13 \cdot 3$ \\
\hline Goodman & & P. Closure & Breast & 145 & $13 \cdot 7$ \\
\hline Page & 1974 & P. Closure & Axillary & 111 & $6 \cdot 6$ \\
\hline \multirow[t]{2}{*}{ Leaper et al. } & 1976 & Conventional & Anorectal & 109 & 33 \\
\hline & & P. Closure & Anorectal & 110 & 10 \\
\hline
\end{tabular}

been used with success. Trials with acute puerperal breast abscesses (Benson \& Goodman, 1970) and axillary abscesses (Page, 1974) have been performed. These concluded that the time taken for healing is significantly less when the abscess cavity is sutured and that it did not produce a higher rate of recurrence. Other studies have been done in which all abscesses regardless of site were included in the study (Table 1). Only two of these studies did not find a significant reduction in healing time (Macfie \& Harvey, 1977; Simms et al., 1982). A study (Macfie \& Harvey, 1977) that included aAB abscesses randomized them into four groups all incized and drained, but two group $\$$ primarily sutured with and without antibiotic cover. They showed no difference in healing time between any of these groups but found a higher recurrence rate in those treated with primary suture. However, they stated that this was due to not always being able to curette the cavity adequately or close the cavity satisfactorily because of its site and size.

The last paper brings one to wonder whether Ellis was correct in his original assumptions about the necessity of antibiotics. A number of different antibiotics have been used prior to incision and primary suture of abscesses, penicillin, or penicillin with streptomycin or sulphonamide (Ellis, 1951, 1953) terramycin (Ellis, 1960), ampicillin and cloxacillin (Leaper et al., 1976). Lincomycin (Leaper et al., 1976; Jones \& Wilson, 1976; Page, 1974; Macfie \& Harvey, 1977), and Clindamycin (Murie, 1981). The study on the management of breast abscesses (Benson \& Goodman, 1970) used variously penicillin and streptomycin, tetracycline and, towards the end of the study, cloxacillin. This would suggest either that the antibiotics make no difference at all as long as curettage is adequate or that the antibiotic used is irrelevant as long as it is active against the bacteria causing the abscess. The bacteria found were staphylococcus aureus for most abscesses with E. Coli in perianal abscesses (Ellis, 1951, 1953, 1960, 1962; Wilson, 1964; Benson \& Goodman, 1970; Page, 1974; Jones \& Wilson, 1976; Howie et al., 1982). The role of antibiotics has been challenged by another trial (Stewart et al., 1985). In a series of 137 acute superficial abscesses randomized to two groups-primary suture and open drainage-both groups were treated with incision, curettage and irrigation with 
hydrogen peroxide. Neither group receiving antibiotics, nevertheless, similar results were obtained to those studies in which antibiotics were used. Primary closure again appeared to be the superior technique.

In view of this review, the present authors' study was conducted to see if other A\&E senior registrars (SRs) were being taught this technique and if this had any influence on their intended future practise.

\section{METHOD}

Fifty-nine questionnaires were sent out to all the A\&E SRs in Great Britain and Northern Ireland. The questionnaires asked for some details of the department in which the SR was training, for details of the management of abscesses in these departments and how they would manage various abscesses in a department of their own, assuming free choice of management. It was felt that this would give a good sample of practice in consultant led departments throughout the country, it would enable us to discover what was actually being taught nationally and to see what the consultants of the future would be doing.

For a list of different abscess types, they were asked whether they were treated in the $A \& E$ department or referred for inpatient treatment and if they were treated in the $A \& E$ department what method of management would be used. Then, for the same list of abscesses, they were asked what they intended to do with them when they were consultants in their own department assuming that they had facilities and free choice of management.

\section{RESULTS}

Fifty-one questionnaires were returned, two replies were excluded as, by the time the reply was returned, they were already consultants in post in their own department. This gave a response rate of $86 \%$ ( 49 out of 57 ).

The 49 completed questionnaires were analysed. The departments in which the SRs worked were very varied seeing between 24000 and 116000 new patients per year. They also had varied facilities, $16 \%$ having no facility for general anaesthetics in the A\&E department, $22 \%$ having no separate 'septic' theatre, $35 \%$ having no observation beds and $6 \%$ having none of the above. Nearly $50 \%$ of the departments had one of the above facilities missing. The absence of a separate theatre or observation beds made no significant difference to the types of abscess managed or to the way they were managed in the A\&E department (0.05 P Chi-squared test). The absence of facilities for general anaesthetics made it significantly more likely that anorectal (ischiorectal or perianal) abscesses would be referred for inpatient management, $(0.05 P$ Chi-squared with Yates correction). The availability of general anaesthetics in the department made no significant difference to how other abscesses were managed.

Only four departments in our survey were using primary closure of abscesses 
routinely. However, 19 SRs intended that, if possible, incision, curettage and primary closure would be departmental policy when they were in charge of their own depart-市 ments. Six of these responses came from the Yorkshire Region and two from people working in the other two departments using primary closure routinely. No one workingo in a department using primary closure intends to stop using primary closure in the future. Furthermore, there is a tendency for those intending to use primary closure for $\frac{\overline{\bar{c}}}{\bar{c}}$ the management of abscesses to increase the range of abscesses that they would be prepared to treat in their own department after becoming a consultant. Whereas, there is a tendency amongst SRs using conventional treatment of abscesses, to reduce the range of abscesses that they would be prepared to treat (Table 3). This difference is significant $(0.05>P$ Chi-squared test).

Table 3 Intended range of abscesses to be treated in their own department by SRs on consultant appointment against intended method of treatment

\begin{tabular}{lccc}
\hline & \multicolumn{3}{c}{ Method } \\
\cline { 2 - 3 } $\begin{array}{l}\text { Range of abscesses } \\
\text { to be treated }\end{array}$ & Primary closure & Conventional & Total \\
\hline Increased & 8 & 6 & 14 \\
Decreased & 1 & 9 & 10 \\
No change & 10 & 15 & 25 \\
Total & 19 & 30 & 49 \\
\hline
\end{tabular}

\section{DISCUSSION}

This study shows that all SRs working in departments using primary closure of abscesses wish to continue doing so on appointment as a consultant. It also showed that another 13 SRs working in departments using conventional treatment for abscesses would like to use primary closure of abscesses in their own departments in the future. $\frac{3}{3}$ These results suggest a degree of satisfaction with primary closure. The SRs who ono consultant appointment will continue to use treatment significantly intend to reduce the range of abscesses treated in their departments. This would suggest that many of these $\mathrm{O}$ SRs find managing abscesses this way to be unsatisfactory. The cost of this in terms of

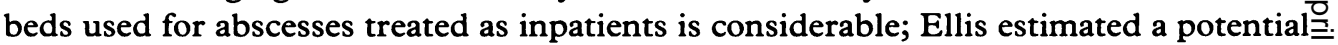
national saving of $£ 500000$ per year in 1953 when a hospital bed cost $£ 15$ per week. N

It would seem from this review that the efficacy of primary closure of abscesses isin backed by the literature, as long as the site and size of the abscess allows adequate $\mathrm{U}_{\mathrm{E}}$ curettage and closure of the abscess cavity. Patients who have 'failed primary suture' ing whom the sutures are removed are no worse off than patients treated conventionally. Ito is the present authors' impression that patients have considerably less pain treated with sutures and this needs studying. Further controlled studies on the requirements for 
antibiotics are also needed. Lastly, as most patients treated by primary suture can be treated as out-patients the savings to the National Health Service could be great. The authors would strongly recommend that primary closure of abscesses be used in all suitable (most) patients.

While the authors would agree that no technique is right for all patients the review of the literature, this survey and their own experience of the technique of primary closure of abscesses would suggest that there cannot be any justification for packing abscess cavities. This traditional but somewhat antiquated technique would appear to actually delay healing and in their experience cause the patient considerably more pain.

\section{REFERENCES}

Benson E. A. \& Goodman M. A. (1970) Incision with primary suture in the treatment of acute puerperal abscess. British fournal of Surgery 57, 55-8.

Buchan R. \& Grace R. H. (1973) Anorectal suppuration: the results of treatment and the factors influencing the recurrence rate. British fournal of Surgery 60, 537-40.

Cuschieri A., Giles G. R. \& Moosa A. (1988) Essential Surgical Practice, 2nd edn, pp. 27-30. John Wright \& Sons Ltd.

Dudley H. (ed.) (1986) Hamilton Bailey's Emergency Surgery, 11th edn. John Wright \& Sons.

Ellis H. \& Calne R. (1987) Lecture Notes on General Surgery, 7th edn. Blackwell Scientific Publications, Oxford.

Ellis M. (1951) The use of penicillin and sulphonamides in the treatment of suppuration. Lancet i, 774-5.

Ellis M. (1953) The treatment of the Ischio-rectal abscess. University of Leeds Medical fournal 2, 84-6.

Ellis M. (1960) Incision and primary suture of abscesses of the anal region. Proceedings of the Royal Society of Medicine 53, 652-4.

Ellis M. (1962) Recurrence of infection following treatment of anorectal abscesses by primary suture. Proceedings of the Royal Society of Medicine 55, 757-8.

Jones N. A. G. \& Wilson D. H. (1976) The treatment of acute abscesses by incision, curettage and primary suture under antibiotic cover. British fournal of Surgery 63, 499-501.

Leaper D. J., Page R. E., Rosenberg I. L., Wilson D. H. \& Goligher J C. (1976) A controlled study comparing conventional treatment of idiopathic anorectal abscess with that of incision, curettage and primary suture under systemic antibiotic cover. Disease of the Colon and Rectum 19, 46-50.

Macfie J. \& Harvey J. (1977) The treatment of acute superficial abscesses: a prospective clinical trial. British fournal of Surgery 64, 264-6.

Murie J. A. (1981) The treatment of acute superficial abscesses, a prospective clinic trial. fournal of the Royal College of Surgeons of Edinburgh 26, 282-5.

Page R. E. (1974) Treatment of axillary abscesses by incision and suture under antibiotic cover. British fournal of Surgery 61, 493-4.

Simms M. H., Curran F., Johnson R. A., Oates J., Givel J. C., Chabloz R. \& Alexander-Williams J. (1982) Treatment of acute abscesses in the casualty department. British Medical fournal 284, 1827-9.

Stewart M. P. M., Laing M. R. \& Krukowski Z. H. (1985) Treatment of acute abscesses by incision, curettage and primary suture without antiobiotics: a controlled clinical trial. British fournal of Surgery 72, 66-7.

Wilson D. H. (1964) The late results of anorectal abscess treated by incision, curettage, and primary suture under antibiotic cover. British fournal of Surgery 51, 828-31. 